\title{
Спектральные характеристики фоточувствительных структур на основе пористого кремния и карбида кремния
}

\author{
Н.В. Латухина ${ }^{1)}$, Д.А. Лизункова ${ }^{1)}$, И.А. Шишкин ${ }^{1)}$, В.В. Танеев ${ }^{1)}$, В.Д. Паранин ${ }^{1)}$ \\ ${ }^{1}$ Самарский национальный исследовательский университет им. академика. С.П. Королева, Самара, \\ 443086, Московское шоссе, 34 \\ тел:+7 (903) 334-7198, эл. почта: natalat@yandex.ru
}

DOI 10.34077/RCSP2019-146

Пористый кремний, получаемый методом анодной электрохимической обработки кремниевых пластин, обладает широким набором уникальных свойств и является перспективным материалом для создания фотоприемников нового поколения [1]. Благодаря развитой системе пор площадь поглощающей поверхности увеличивается, а спектральная чувствительность расширяется в коротковолновую область за счет увеличения ширины запрещенной зоны кремния в нано-размерных кремниевых образованиях, локализующихся на стенках пор или в оксидном слое вблизи стенок. Поэтому простейшей моделью электронной структуры пористого кремния может быть система неупорядоченных квантово-размерных образований различной структуры. В настоящей работе производилась исследование спектральных характеристик фоточувствительных структур на основе пористого кремния и карбида кремния и оценка применимости такой модели к пористому кремнию, созданному на разных типах подложек.

Для создания пористого слоя пластины кремния подвергались электрохимическому травлению в ячейке вертикального типа в водно-спиртовых растворах плавиковой кислоты. Использовались монокристаллические пластины кремния с ориентацией поверхности по кристаллографической плоскости (100) или (111), поверхность которых была шлифованной или текстурированной. Спектры отражения снимались на спектрофотометре Shimadzu UV-2450 с приставкой 206-14046. Диапазон измерения составил 0,3 - 1 мкм, шаг измерения и спектральная ширина щели монохроматора - 2 нм, скорость сканирования - средняя.

Исходя из анализа экспериментально полученных спектральных характеристик коэффициента отражения, была проведена оценка применимости разработанной модели для ПК того или иного типа. Для структуры с ориентацией (100) характерны поры в виде столбиков, т.е. более применимой является модель квантовых нитей, как и для карбида кремния, а для ориентации (111) кораллоподобные структуры (модель квантовых точек) или столбики, расположенные под углом 45 градусов (модель квантовых нитей). В модели диаметр квантовой нити варьировалась от 0.1 до 100 нм, квантовой точки от 4 до 100 нм. Ширина запрещенной зоны квантово-размерных рассчитывалась по формуле:

$$
E_{g}=E_{g_{\mathrm{e}}}+\Delta E_{n}+\Delta E_{p},
$$

где $\mathrm{E}_{\mathrm{g} 0}$ - ширина запрещенной зоны объемного материала (кремния 1,12 эВ, карбида кремния кубической модификации 2,33 эВ), $\Delta \mathrm{E}_{\mathrm{n}}$ и $\Delta \mathrm{E}_{\mathrm{p}}$ - квантово-размерные добавки для электронов и дырок, соответственно.

Расчеты показали, что увеличение фоточувствительности образцов с пористым кремнием и карбидом кремния в коротковолновой части спектра может объясняться наличием в их структуре массивов квантовых нитей и(или) квантовых точек с характерным размером от1 нм до 100 нм.

\section{Лuтература}

[1] Латухина Н.В. и др. // Известия СНЦ РАН, 2009, Т.11, №3, с.66 - 70 